\title{
Legalitas Badan Usaha Pada Masyarakat Desa Daratan Kempas Kecamatan Tebing Tinggi Kabupaten Tanjungjabung Barat Dalam Rangka Peningkatan Ekonomi Kreatif
}

\author{
Yetniwati, Taufik Yahya, Diana Amir \\ Fakultas Hukum, Universitas Jambi, Indonesia
}

\begin{abstract}
ABSTRAK
Penyuluhan hukum dilaksanakan adalah untuk menambah pengetahuan dan wawasan masyarakat sasaran. Adapun tujuan penyuluhan ini adalah: 1. untuk memberikan gagasan, dan pemahaman masyarakat tentang persyaratan melegalitas suatu badan usaha; 2. untuk memberikan gagasan, dan pemahaman masyarakat tentang proses melegalitas suatu badan usaha. Sebelum penyampaian materi terlebih dahulu dilakukan survey awal terhadap 25 orang masyarakat sasaran. Metode pelaksanaan dengan melakukan ceramah, tanya jawab. Hasil survey awal, sebelum dilaksana penyampaian materi hasil survei menunjukan bahwa pengetahuan masyarakat tentang legalitas badan usaha sangat kurang sekali dari 12 pertanyaan yang diajukan pada kuisioner . Pengukuran penambahan tingkat pengetahuan masyarakat sasaran dilakukan dengan melakukan survei ulang dengan mengedarkan kuisioner yang sama kembali. Setelah dilakukan penyampaian materi penyuluhan berupa pengertian, jenis, persyaratan dan prosedur mendirikan badan usaha, ditemukan $80 \%$ dari materi penyuluhan dapat dipahami masyarakat sasaran. Akhirnya masyarakat berminat untuk mendaftarkan merek usaha dan berencana akan mendirikan Perseroan Terbatas, hal ini nanti tergantung pada kondisi keuangan masyarakat.
\end{abstract}

Kata kunci: pengetahuan , masyarakat, legalitas, badan usaha .

\section{PENDAHULUAN}

Desa Daratan Kempas yang terletak di Kecamatan Tebing Tinggi Kecamatan Tanjung Jabung Barat, bila ditempuh dengan angkutan jalan darat berjarak lebih kurang $140 \mathrm{~km}$ dari Ibu Kota Propinsi Jambi, atau berjarak lebih kurang $130 \mathrm{~km}$ dari Kota Kuala Tunggal ibu kota Kabupaten Tanjung Jabung Barat. Desa ini diperintah oleh seorang Kepala Desa yang bernama Asbar Nofendra untuk periode 2016 sampai dengan tahun 2021. Desa ini dihuni oleh 1863 penduduk, dengan 502 kepala keluarga, terdiri dari 3 dusun dan 13 Rukun Tetangga.

Desa Daratan Kempas termasuk salah satu desa binaan Universitas Jambi, desa ini sudah mempunyai misi sebagai berikut:

1. Mewujudkan masyarakat yang rukun, damai, dan harmonis;

2. Mewujudkan pemerintah desa yang tertib, bersih, dan mampu manjadi pelayan masyarakat;

3. Meningkatkan Kesejahteraan masyarakat yang bersumber pada potensi dan sumber daya yang dimiliki desa;

4. Meningkatkan kualitas dan kuantitas infrastruktur dan sarana prasarana umum;

5. Meningkatkan polatanah dan hasil produk sipertanian. Meningkatkan pelayanan kesehatan dan lingkungan;

6. Meningkatkan mutu pendidikan;

7. Meningkatkan kegiatan sosial budaya masyarakat yang serasi dan seimbang; 
8. Meningkatkan pelayanan masyarakat dibidang pemerintahan . Meningkatkan ketertiban masyarakat.

Sebagai desa binaan Universitas Jambi menginginkan desa Daratan Kempas menjadi desa agrowisata dan eduwisata, yaitu desa tempat wisata yang sasarannya daerah pertanian juga bersifat edukatif. Desa Daratan Kempas merupakan daerah Perkebunan Sawit, yang pada tahun 2023 harus Replanting karena pohon sawitnya sudah berusia 20 tahun. Untuk mengatasi masalah Replanting yang waktu nya masih lama, karena menunggu penetapan dari pemerintah dan untuk mengatasi masalah pengangguran maka masyarakat telah melakukan berbagai usaha, diantaranya : olah limbah tandan sawit menjadi pupuk organik sebagai Produk Unggulan Kawasan Perdesaan (Prukades), home industry (industri rumah tangga) jamu jahe kering, olah limbah plastik, taman wisata. Di desa ini terdapat 17 kelompok tani yang bergerak dibidang perkebunan sawit, usaha pengembangan kompos, ternak sapi, ternak domba, budidaya ikan air tawar, budidaya jahe merah, budidaya tanaman pangan. Usaha dominan dari kelompok tani adalah produksi kompos yang berasal dari limbah kering sawit yang dicampur dengan kotoran ternak. Untuk mengisi kegiatan menjelang Replanting semua mereka sudah bersiap diri mengatasi pengangguran menjelang Replanting tiba, akan tetapi badan usaha mereka belum berbentuk badan hukum. Hal ini penting sekali bagi mereka dalam hal kepastian hukum untuk mengadakan transaksi menjual kompos ke pemasok.

Legalitas badan usaha adalah suatu upaya mendaftarkan badan usaha agar adanya kepastian hukum tentang berdirinya, status, domicili, struktur organisasi, eksistensi dan kewenangan suatu badan usaha. Legalitas badan usaha sangat penting bagi pengurus atau organ badan usaha, agar badan usaha mereka dapat dilindungi oleh hukum. Legalitas badan usaha dimulai dari proses berdiri, kemudian pendaftaran pada instansi yang berwenang.

Badan usaha itu bermacam-macam bentuknya, ada badan usaha perseorangan dan juga badan usaha persekutuan. Badan usaha persekutuan ada yang berbentuk badan hukum dan ada juga bukan badan hukum.

Kepala desa bersama beberapa kelompok tani datang ke kampus Program Studi Magister Kenotariatan Universitas Jambi untuk meminta pendampingan dalam proses legalitas usaha yang bergerak dibidang pengembangan kompos dan berbagai macam usaha perekonomian. Penyuluhan hukum ini bertujuan untuk menyampaikan materi legalitas badan usaha secara garis besar mengenai : pengertian, jenis badan usaha, persyaratan dan proses pembentukan badan hukum yang harus dilakukan untuk melegalitas badan usaha di Desa Daratan Kempas.

\section{METODE PELAKSANAAN}

Kegiatan penyuluhan dilaksanakan dari survey awal sebelum penyampaian materi, penyamapian materi penyuluhan, tanya jawab, evaluasi kembali tingkat pengetahuan masyarakat sasaran setelah penyampaian materi.

\section{HASIL DAN PEMBAHASAN}

\section{Hasil Survei Awal}

Hasil survei awal menunjukan bahwa Desa Daratan Kempas merupakan salah salah satu desa yang berasal dari pemekaran wilayah yang dulunya adalah Dusun Arum Sari yang merupakan bagian dari Desa Purwodadi. Pada tahun 2012 desa ini dipimpin oleh M.Hatta Nasir, kemudian Tahun 2015 sebagai Pjs kepala Desa dipimpin oleh Sudirman SE yang juga merangkap menjadi Sekretaris Camat Kecamatan Tebing Tinggi. Pada tanggal 19 Mei tahun 2016 dilakukan 
pemilihan Kepala Desa, dan Kepala Desa yang terpilih adalah Asbar Nofendra yang diangkat untuk masa jabatan periode 2016 sampai 2021.

Pada hari pelaksanaan penyuluhan yaitu tanggal 9 Juli tahun 2020 di kantor Desa Daratan Kempas yang dihadiri oleh Sekretaris Desa, Ketua Kelompok Tani dan beberapa orang anggota kelompok tani, Ketua PKK dan anggota pengurus PKK, pemuka masyarakat, dan anggota masyarakat, semua berjumlah 22 masyarakat sasaran, ditambah dengan 3 orang mahasiswa prodi Magister Kenotariatan ( 2 orang mahasiswa yang diundang berhalangan hadir). Kepala Desa tidak datang karena menghadiri pemakaman saudaranya saudaranya yang meninggal di Kota Jambi. Sebelum penyampaian materi dilakukan, dilaksanakanlah pengukuran tingkat pengetahuan masyarakat sasaran, sebagaimana tabel berikut.

Tabel 1. Tingkat Pemahaman Masyarakat Sasaran Sebelum Penyuluhan

\begin{tabular}{|c|l|c|c|c|}
\hline No. & Bentuk pertanyaan tentang & $\begin{array}{l}\text { Frekwensi } \\
\text { jawaban } \\
\text { yang betul }\end{array}$ & $\begin{array}{l}\text { Frekwensi } \\
\text { jawaban } \\
\text { yang salah }\end{array}$ & Jumlah \\
\hline 1. & Pengertian badan usaha & 3 & 19 & 22 \\
\hline 2. & Jenis badan usaha berbadan hukum & 2 & 20 & 22 \\
\hline 3. & Jenis badan usaha bukan badan hukum & 2 & 20 & 22 \\
\hline 4. & $\begin{array}{l}\text { syarat mendirikan badan usaha bukan } \\
\text { badan hukum }\end{array}$ & 1 & 21 & 22 \\
\hline 5 & $\begin{array}{l}\text { syarat mendirikan badan usaha } \\
\text { berbadan hukum }\end{array}$ & 0 & 22 & 22 \\
\hline 6. & $\begin{array}{l}\text { Proses mendirikan badan usaha bukan } \\
\text { berbadan hukum }\end{array}$ & 0 & 22 & 22 \\
\hline 7 & $\begin{array}{l}\text { Proses mendirikan badan usaha } \\
\text { berbadan hukum }\end{array}$ & 0 & 22 & 22 \\
\hline 8. & Pengertian CV & 1 & 21 & 22 \\
\hline 9. & Usaha kecil, menengah & 6 & 16 & 22 \\
\hline 10 & Pengertian koperasi & 2 & 20 & 22 \\
\hline 11. & Surat izin usaha & 4 & 18 & 22 \\
\hline 12. & Berakhirnya/bubarnya badan usaha & & & 22 \\
\hline
\end{tabular}

Sumber data: hasil survei tanggal 9Juli 2020

Dari hasil pertanyaan yang disampaikan sebagian besar lebih dari 50\% mereka tidak tahu tentang legalitas perusahaan.

\section{Penyampaian Materi Bahan Hukum}

Bentuk- bentuk Badan Usaha

Suatu badan usaha selalu mempunyai bentuk, baik berbentuk usaha perseorangan atau persekutuan, sedangkan badan usaha persekutuan ada yang badan hukum atau bukan badan hukum. Badan usaha perseorangan adalah badan usaha yang dimilki dan dikelola oleh perseorangan secara individu, termasuk dalam arti dikelola oleh satu keluarga. Sedangkan usaha persekutuan adalah usaha yang dimiliki dan dikelola oleh beberapa orang yang telah membuat perjanjian mendirikan badan usaha secara bersama. Badan usaha persekutuan terdiri atas dua jenis, yaitu badan usaha berbentuk badan hukum dan ada juga bukan badan hukum. Badan usaha persekutuan yang bukan badan hukum adalah: persekutuan perdata, firma ( $\mathrm{Fa}$ ), Commanditair Venootchap (CV). Prosedur pendirian persekutuan perdata secara garis besarnya adalah membuat akta pendirian perusahaan melalui akta notaris. Setelah Akta pendirian perusahaan diperoleh maka diuruslah pengesahan nama perusahaan kepada Kementerian Hukum dan HAM RI secara online atau manual . Tujuan pendaftaran nama 
perusahaan perlu didaftarkan adalah agar nama perusaan yang diusulankan tidak sama dengan nama perusahaan terdahulu telah terdaftar. Setelah nama perusahaan disetujui, kemudian diajukan lagi pendaftaran perusahaan kepada Kementerian Hukum dan HAM dengan lampiran berupa bukti Pembayaran biaya pendaftaran, pengisian formulir pendaftaran dan dokumen pendukung. Kemudian Menteri menerbitkan Surat Keterangan Terdaftar (SKT) CV, Firma, dan Persekutuan Perdata pada saat permohonan diterima. SKT tersebut dikembalikan oleh Kemenkum dan HAM kepada Notaris untuk ditanda tangani, serta memuat frasa yang menyatakan "Surat Keterangan Terdaftar ini dicetak dari Sistem Administrasi Badan Usaha". Berkas ini kemudian dikirim atau upload lagi kepada Kemenkum dan HAM, untuk diterbitkan Surat Keputusan Pendirian CV, atau Firma, atau Persekutuan Perdata. Kemudian untuk mulai berusaha maka diuruslah: ; Nomor Pokok Wajib Pajak (NPWP) perusahaan di kantor Pajak setempat; Surat Izin Usaha Perdagangan (SIUP).

\section{Badan Usaha Badan Hukum}

Badaan usaha berbentuk badan hukum ini dapat memiliki hak-hak dan kewajiban-kewajiban serta melakukan perbuatan-perbuatan hukum seperti manusia, bahkan juga dapat memiliki kekayaan sendiri, proses pendiriannya diatur oleh peraturan perundang-undang lainnya. Namun demikian, yang bertindak ke luar atas nama badan hukum tersebut adalah para pengurusnya, atau dengan kata lain pengurusnya tersebut hanyalah merupakan alat atau organ dari badan hukum untuk melakukan perbuatan hukum. Dan mengenai kekuasaan pengurusnya untuk bertindak ke luar atau melakukan perbuatan hukum, dapat dilihat dari anggaran dasarnya/akta pendirian badan hukum tersebut, contohnya: Perseroan Terbatas (PT), Koperasi, BUMN, BUMD, BUMDES, Yayasan. Adapun badan usaha berbadan hukum dijelaskan selanjutnya. .

\section{Perseroan Terbatas (PT)}

Pengertian Perseroan Terbatas menurut Undang-undang Nomor 40 Tahun 2007 tentang Perseroan Terbatas yang seterusnya ditulis UUPT adalah badan hukum yang merupakan persekutuan modal, didirikan berdasarkan perjanjian, melakukan kegiatan usaha dengan modal dasar yang seluruhnya terbagi dalam saham dan memenuhi persyaratan yang ditetapkan dalam Undang-Undang ini serta peraturan pelaksanaannya. Artinya suatu badan usaha yang akan berbentuk Perseroan Terbatas harus memiliki modal yang terdiri dari saham-saham sebagai harta kekayaan perseroan terdiri dari : benda bergerak maupun tidak bergerak, baik benda berwujud maupun tidak berwujud semua terpisah dari harta kekayaan pribadi anggotanya. Prosedur pendiriannya harus sesuai dengan ketentuan perundang-undangan yang berlaku, yaitu: Undang-Undang Nomor 40 Tahun 2007 tentang Perseroan Terbatas; 2). Peraturan Menteri Hukum dan HAM nomor 4 tahun 2014 tentang Tata Cara Pengajuan Permohonan Pengesahan Badan Hukum dan Persetujuan Perubahan Anggaran Dasar Serta Penyampaian Pemberitahuan Perubahan Angaran Dasar dan Perubahan Data Perseroan Terbatas, yang kemudian direvisi oleh Peraturan Menteri Hukum dan HAM nomor 1 tahun 2016.

Perseroan Terbatas dalam menjalankan kegiatannya akan dilaksanakan oleh organnya yaitu: Rapat Umum Pemagang Saham, Direksi, dan Komisaris. Rapat Umum Pemegang Saham yang dikenal dengan RUPS mempunyai kedudukan yang tertinggi dalam perusahaan, dan berwenang mengangkat Direksi dan Komisaris. Direksi adalah orang mengurus perusahaan dan bertanggung jawab kepada RUPS. Direksi terdiri dari Direktur Utama yang membawahi beberapa direktur. Sedangkan Komisaris adalah Organ Perseroan yang bertugas melakukan pengawasan secara umum dan/atau khusus sesuai dengan anggaran dasar serta memberi nasihat kepada Direksi . 
Pendirian Perseroan Terbatas : setiap pendirian PT terlebih dahulu harus dibuat Akta Pendirian Perusahaan melalui Notaris. Para pendiri menghadap Notaris menyampaikan rancangan anggaran dasar, beserta dokumen NPWP, SPT Pajak, Akta ini berisikan rancangan Anggaran dasar dan rancangan anggaran rumah tangga perusahaan. Setelah akta pendirian dari Notaris diperoleh, kemudian diajukan pengesahan nama perusahaan kepada KementerianHukum dan HAM Republik Indonesia secara online lebih cepat. Setelah pengesahan nama perusahaan diperoleh, kembali diajukan permohonan untuk mendapatkan legalitas sebagai badan hukum kepada Kementerian Hukum dan Hak Asasi Manusia, ini dapat dilakukan oleh pemohon sendiri atau notaris secara on line, namun situs pendaftaran secara online hanya ada pada notaris melalui Sistem Administrasi Badan Hukum (SABH).

Tujuan pendaftrannya adalah agar mendapatkan pengesahan sebagai badan hukum yang bernama PT (nama perusahaan). Setelah mendapatkan sertifikat Badan Hukum yang berbentuk PT (nama perusahaan), maka pemohon dapat mengajukan Surat Izin Usaha Perdagangan pada Dinas Perdagangan dan perindustrian setempat, dan Surat izin tempat usaha yang sekarang bernama SKDP dari Pemerintahan Daerah setempat yang tujuannya adalah agar usaha perdagangan atau perindustrian legal melakukan usahanya. Surat izin harus diajukan ke instansi terkait sesuai dengan jenis usaha.

\section{Koperasi}

Koperasi ini diatur oleh Undang-Undang Nomor 25 Tahun 1992 tentang Perkoperasian, termasuk segala peraturan pelaksanaannya yang menjadi dasar dari berdiri dan beroperasinya koperasi-koperasi yang ada saat ini. Pada Pasal 1 disebutkan bahwa koperasi adalah suatu badan usaha yang beranggotakan orang seorang atau badan hukum koperasi dengan melandaskan kegiatannyai berdasarkan prinsip koperasi sekaligus sebagai gerakan ekonomi rakyat yang berdasar atas asas kekeluargaan.

Dari segi fungsi dan kebutuhannya, koperasi ini antara lain dapat berupa: a). Koperasi Simpan Pinjam; b). Koperasi Konsumsi; c). Koperasi produksi; d). Koperasi serba usaha. Koperasi simpan pinjam yaitu koperasi yang bertujuan untuk membantu anggotanya melalui perjanjian pinjam uang. Kopersi konsumsi adalah koperasi yang kegiatan berjualan barang-barang untuk memenuhi kebutuhan anggota yang bersifat konsumtif. Koperasi produksi yaitu kopersi yang kegiatannya bertujuan untuk membantu anggotanya dalam kegiatan yang bersifat produktif, seperti kegiatan memasok bahan baku bagi kelompok tani. Koperasi serba usaha yaitu koperasi yang melakukan berbagai kegiatannya, menggabungkan kegiatan yang bersifat produkstif dan konsumtif, bahkan ada yang memberikan jasa pelayanan.

Prosedur pendirian koperasi berawal dari rapat para pendiri ( minimal 20 orang) dan didampingi oleh pejabat Dinas Perkoperasian, yang membahas mengenai nama koperasi, rancangan anggaran dasar dan rancangan anggaran rumah tangga koperasi, kemudian diajukan pembuatan akta pendirian koperasi di Kantor Notaris. Menurut Permenkumham nomor 14 tahun 2019 mensyaratkan agar permohonan pengesahan akta ini dimuat atau dinyatakan dalam akta notaris dalam bahasa Indonesia. Setelah akta pendirian diperoleh dilakukan pendaftaran ke Kementerian Hukum dan Hak Asasi Manusia untuk mendapat keputusan dan pengesahan sebagai badan hukum. Setelah surat keputusan pengesahan sebagai badan hukum diperoleh maka dilanjutkan dengan surat izin usaha dari Dinas Koperasi yang sekarang bernama Dinas Perdagangan dan Koperasi. Setelah mendapat surat izin usaha dan izin tempat usaha, maka koperasi legal beroperasi.

\section{KESIMPULAN DAN SARAN}


Tingkat pengetahuan masyarakat tentang legalitas badan usaha akan bertambah setelah dilaksanakan penyuluhan hukum kepada masyarakat sasaran mengenai: 1.Syarat-syarat legalitas badan usaha, dan perlindungan merek usaha kerakyatan; 2. Prosedur legalitas badan usaha baik yang berbentuk badan hukum maupun (PT, Koperasi) badan usaha bukan badan hukum (persekutuan perdata, CV, Fa).

Dari hasil kegiatan ini, disarankan kepada masyarakat Desa Daratan Kempas segeranya melegalitas badan usaha yang belum terdaftar. Rencana akan mendirikan Perseroan Terbatas atau Merubahan Anggaran Dasar Koperasi, perlu dirapatkan dulu dengan masyarakat, kelompok tani, perangkat desa. Selanjutnya, perlu dilakukan pendaftaran merek atas produksi di desa mereka ke kantor Dirjend HKI melalui Kanwil Kemenkumham Propinsi Jambi, agar produksi mereka terlindungi oleh hukum .

\section{DAFTAR PUSTAKA}

B.Arief Sidharta (alih bahasa) 2013, Struktur Ilmu Hukum, Alumni, Bandung.

Herlien Budiono, 2017, Dasar Teknis Pembuatan Akta Notaris, Citra Aditya Bakti, Bandung. Republik Indonesia, Undang-undang Nomor 25 Tahun 1997 tentang Perkoperasian Republik Indonesia, Undang-undang Nomor 40 Tahun 2007 tentang Perseroan Terbatas.

Republik Indonesia, Peraturan Menteri Hukum dan HAM nomor 4 tahun 2014 tentang Tata Cara Pengajuan Permohonan Pengesahan Badan Hukum dan Persetujuan Perubahan Anggaran Dasar Serta Penyampaian Pemberitahuan Perubahan Angaran Dasar dan Perubahan Data Perseroan Terbatas .

Republik Indonesia, Peraturan Menteri Hukum dan HAM nomor 1 tahun 2016 tentang Perubahan Peraturan Menteri Hukum dan HAM nomor 4 tahun 2014 tentang Tata Cara Pengajuan Permohonan Pengesahan Badan Hukum dan Persetujuan Perubahan Anggaran Dasar Serta Penyampaian Pemberitahuan Perubahan Angaran Dasar dan Perubahan Data Perseroan Terbatas .

Republik Indonesia, Peraturan Menteri Hukum dan HAM nomor 14 tahun 2019 tentang Pengesahan Koperasi

https://panduan.ahu.go.id/doku.php?id=perseroan_terbatas diakses 2 Maret 2020.

https://kinciakincia.com/berita/2481-kini-pendaftaran-koperasi-dengan-sistem-online.html diakses 1 Maret 2020.

https://jambi.tribunnews.com/2018/05/05/selain-pupuk-kompos-desa-dataran-kempas-jugainovasikan-keuangan-mikro diakses 2 Juli 2020

https://www.infodesa.id/jambi/12/06/2019/profil-desa-dataran-kempas-kec-tebing-tinggi-kabtanjung-jabung-barat/ diakses 2 Juli 2020 